Article

\title{
Integrating Green Infrastructure into Urban Planning: Developing Melbourne's Green Factor Tool
}

\author{
Judy Bush ${ }^{1, *}$, Gavin Ashley ${ }^{2}$, Ben Foster ${ }^{3}$ and Gail Hall ${ }^{3}$ \\ ${ }^{1}$ Faculty of Architecture, Building and Planning, The University of Melbourne, Parkville, VIC 3010, Australia; \\ E-Mail: judy.bush@unimelb.edu.au \\ 2 HIP V. HYPE Sustainability, Brunswick, VIC 3056, Australia; E-Mail: gavin@hipvhype.com \\ ${ }^{3}$ City of Melbourne, Melbourne, VIC 3000, Australia; E-Mails: ben.foster@melbourne.vic.gov.au (B.F.), \\ gailanghall@hotmail.com (G.H.) \\ * Corresponding author
}

Submitted: 28 July 2020 | Accepted: 29 September 2020 | Published: 26 January 2021

\begin{abstract}
As cities increase in size and density, the ecosystem services supplied by urban greenery and green infrastructure are increasingly vital for sustainable, liveable urban areas. However, retaining and maximising urban greenery in densifying cities is challenging. Governments have critical roles in addressing these challenges through policy development and implementation. While there has been significant attention on the quality and quantity of green space on public land, there is an increasing focus on policy mechanisms for integrating green infrastructure into the private realm, including green roofs, walls, facades, balconies and gardens. As part of City of Melbourne's efforts to increase greening across the municipality, its 2017 Green Our City Strategic Action Plan includes specific focus on the private realm, and development of regulatory processes for green infrastructure. This article reports on a participatory research project to develop a Green Factor Tool for application to building development proposals in Melbourne. We focus on the transdisciplinary collaborations that brought together contributions from researchers, practitioners, policymakers and designers. We discuss how local research on green space contributions to provision of ecosystem services shaped the design of the tool and provided the tool's rigorous evidence-base. Finally, we consider the roles of urban planning in retaining and maximising urban green spaces in densifying urban areas.
\end{abstract}

\section{Keywords}

biodiversity; climate change; ecosystem services; green; planning tools; regulation; sustainability; urban planning

\section{Issue}

This article is part of the issue "Urban Planning and Green Infrastructure" edited by Paul Osmond (University of New South Wales, Australia) and Sara Wilkinson (University of Technology Sydney, Australia).

(C) 2021 by the authors; licensee Cogitatio (Lisbon, Portugal). This article is licensed under a Creative Commons Attribution 4.0 International License (CC BY).

\section{Introduction}

Urban green spaces contribute a wide range of functions, services and benefits towards creating more liveable and sustainable cities. Urban green spaces mitigate urban heat (Santamouris et al., 2018, pp. 6, 27), contribute to managing water runoff quantity and quality (Liu \& Jensen, 2018), provide spaces for recreation, exercise and social activities (Kabisch, van den Bosch, \& Lafortezza, 2017), as well as food growing and commu- nity gardens (Egerer et al., 2018), and habitat for biodiversity (Parris et al., 2018), with cities being home to proportionally high numbers of threatened (Ives et al., 2016) as well as more common species of fauna and flora (Kowarik, Fischer, \& Kendal, 2020). Urban green spaces provide multiple functions (Hansen \& Pauleit, 2014), even if they have been designed primarily for a single purpose. These multiple ecosystem functions have been described and categorised as 'ecosystem services' by the Millennium Ecosystem Assessment (2003). 
Ecosystem services highlight the benefits provided to people, society and biodiversity by ecosystems. Since the Millennium Ecosystem Assessment landmark report in 2003, there has been substantial research focus highlighting the functions, benefits and values of ecosystem services, including in cities and towns (including for example, Connop et al., 2016; Cortinovis \& Geneletti, 2018; Gómez-Baggethun et al., 2013; Haase et al., 2014; Hansen et al., 2015).

Local governments are increasingly focusing on greening the public realm through the planting of street trees and the creation and ongoing management of parks, gardens, town squares and other public spaces. However, greening on private land is also important, yet the mechanisms with which governments can influence this are often limited. To address this policy gap, several cities globally have developed green infrastructure assessment tools for application to building development proposals, including 'Green Factor Tools' in Seattle, Helsinki, Malmö and Singapore (Juhola, 2018; Kruuse, 2011; Ong, 2003; Slätmo, Nilsson, \& Turunen, 2019). In Australia, the City of Melbourne (the central city municipality of greater metropolitan Melbourne) is working to increase greening across the municipality. The Green Our City Strategic Action Plan (CoM, 2017) focuses specifically on greening the private realm, and includes actions to develop and improve regulatory processes for integrating green infrastructure into new buildings and urban developments. The development of the Green Factor Tool is one of the actions explicitly listed in the strategy (CoM, 2017, p. 22).

This article presents the process of development of the Green Factor Tool for application to building development proposals in the City of Melbourne. We focus on the transdisciplinary collaborations that brought together contributions from researchers, practitioners, policymakers and designers. In the next section, we highlight the intersections between greening and land use planning, and introduce the policy background for development of the tool. The following section presents the stages of the tool's development, including the processes to construct the research evidence base that underpins the tool's structure and function. We show how the tool was customised for the Australian context, with considerable input from local research on how urban green space contributes to the provision of ecosystem services. The discussion focuses on the stages of policy development within City of Melbourne, and how the Green Factor Tool contributes to the city's suite of greening approaches. The City of Melbourne intends the tool to be applicable across the municipality, which includes both high density, multi-storey buildings, as well as areas of lower density, single or double-storey buildings. We conclude by reflecting on how the development of the tool highlights the potential for urban planning mechanisms to contribute to retaining and maximising urban green spaces in densifying urban areas.

\section{Urban Greening and Land Use Planning}

There is an increasing focus on the importance of 'urban greenery' (including green infrastructure and naturebased solutions) for sustainable and resilient cities, and the roles of policies in the provision of urban green spaces (Bush \& Doyon, 2019; Cohen-Shacham, Walters, Janzen, \& Maginnis, 2016; IPBES, 2019). Increasingly, urban land use policies are addressing green space provision as part of land use planning (Meerow, 2020; Scott et al., 2016). In addition, local and regional governments are developing urban forest, biodiversity and urban nature strategies (Aalbers, Kamphorst, \& Langers, 2019; Bush, 2020; Pauleit et al., 2018). Recent initiatives, such as the CitiesWithNature platform, highlight the work of more than 170 cities across more than 50 countries that are actively working to integrate urban nature into city planning, development and management. In Melbourne, Australia, there has been considerable focus on greening policy and implementation. Melbourne is Australia's second largest city, with 32 local governments across the metropolitan area. The City of Melbourne (the central city's local government) has released a suite of greening strategies since the 2012 publication of its urban forest strategy (CoM, 2012). In 2019, Resilient Melbourne and The Nature Conservancy, in partnership with the 32 local governments, expanded the urban forestry approach to create a strategy for the whole metropolitan region (TNC \& RM, 2019); and an increasing number of metropolitan Melbourne local governments are now developing urban forest strategies for their municipalities (Phelan, Hurley, \& Bush, 2018).

While there has been a significant focus on the importance of retaining and maximizing greenery on public land, a substantial proportion of urban green space is located in the private realm, including in residential gardens (Marshall, Grose, \& Williams, 2019). In the City of Melbourne, the local government owns and controls less than one third of the city's land area (CoM, 2017). While greening the public realm, in streets, parks, gardens and waterways, is essential for creating liveable, sustainable and resilient cities, a focus on private realm greening is also necessary to meet municipal greening and environmentally sustainable design targets, including increasing canopy cover; reducing water pollution associated with runoff; and increasing biodiversity, habitats, and ecosystem health, with the private realm identified as "playing a significant role in supporting nature in the city" (CoM, 2017, p. 27). Green infrastructure in private property is an important yet under-examined aspect of urban land use planning, with the majority of local government greening actions, as well as urban greening research focused on greening the public realm (Meerow, 2020). Furthermore, much of the attention on urban greening has focused on tree cover and urban forestry, with significantly less work on green roofs and vertical greening (Bathgate et al., 2020). There is a need to develop rigorous and effective policy mechanisms for retaining 
and maximising green space within the private realm. Policies, particularly requirements within land use planning provisions, can play a key role in targeting greening in new developments (Bush, 2020).

The City of Melbourne's suite of greening policies addresses a range of contexts and opportunities. While its 2012 Urban Forest Strategy made reference to 'green infrastructure,' including green roofs and vertical greening, the key focus was largely tree cover in streets and parks (CoM, 2012). Nonetheless, the strategy underpinned municipal efforts to develop skills, capacity and actions associated with greening the private realm, including development of the Growing Green Guide, a report providing an evidence base and technical guide for installation of green roofs, walls and facades (Victorian Department of Environment and Primary Industries, 2014). The City of Melbourne also undertook assessment of greening opportunities in the dense central city area (CoM, 2014), and offered grants to encourage implementation, through the Green Your Laneway pilot program (CoM, 2017). To specifically address greening the private realm, as well as to further encourage green roof and vertical greening implementation, the City of Melbourne released its Green Our City Strategic Action Plan in 2017 (CoM, 2017). In addition to 'leading by example,' developing and maintaining partnerships with Green Building Council of Australia and other groups, advocacy to other local governments and state government, the action plan explicitly includes a focus on development of regulatory mechanisms to require greening as part of new developments in the municipality.

As cities become increasingly dense, policy mechanisms for ensuring integration of greenery in new developments need to encompass the provision of green roofs, walls and facades, in addition to the greenery included in ground-level gardens. Therefore, policy mechanisms are required that can quantify both groundlevel garden space and permeable undeveloped space, and the contribution of building-integrated greenery. Several cities have developed assessment tools for application during the planning and design phases for new buildings. Berlin was one of the first cities to introduce an assessment tool, with the Biotope Area Factor introduced in 1994 (Climate-ADAPT, 2016). These tools provide mechanisms for quantifying the amount of greenery integrated into new developments, frequently in the form of a numerical value for the ratio between the built areas and green areas of the property or lot (Juhola, 2018).

These existing tools have provided the inspiration for City of Melbourne's development of its Green Factor Tool (CoM, 2017; GHD, 2013). In developing the Melbourne Green Factor Tool, City of Melbourne aimed to create a rigorous, evidence-based tool customised for local conditions, that would contribute towards meeting a range of its policy objectives, as well as environmentally sustainable design targets (CoM, 2017, pp. 6, 27). Further, the development of the tool for Melbourne aimed to strengthen or improve on key features of existing tools from other cities. While there has been only limited research on green factor tools globally, with most of the research focused on simply identifying or describing tools rather than critically analysing their coverage or performance, Juhola (2018) review of Helsinki's tool, highlighted that key improvements could be made in relation to monitoring of the tool's application, and in setting ambitious targets that developers must meet. City of Melbourne also undertook several comparative assessments of the strengths and weaknesses of a range of these tools (CoM, 2017; GHD, 2013). These reviews contributed to the initial planning for the development of Melbourne's Green Factor Tool, but also highlighted the necessity for further targeted research as part of the tool development process (CoM, 2017). As the ultimate objective is to pursue changes to the planning scheme to make the use of the tool mandatory in the development process, the tool needed to be based on credible and defendable research, with a specific focus on local research, to ensure it is resilient to scrutiny.

There is currently little published research of how green rating tools are developed and applied (Ade \& Rehm, 2020; Juhola, 2018; Kruuse, 2011; Slätmo et al., 2019), or their comparative strengths, weaknesses or opportunities for improvement or extension; this case study seeks to contribute to this body of knowledge by presenting the process for research, development and piloting of the City of Melbourne's Green Factor Tool.

\section{Green Factor Tool Development}

The development of the Green Factor Tool was undertaken between April and June 2019, followed by testing and modification to the end of 2019, and the tool's launch, for voluntary usage, in May 2020. The development process involved a comprehensive, transdisciplinary collaboration between policymakers, sustainable building and landscape practitioners, software designers and researchers. The consultancy team appointed by City of Melbourne to develop the tool was led by HIP V. HYPE Sustainability, with tool and website design by Little Sketches, and research input from University of Melbourne researchers. This article focuses primarily on the research input, which contributed both to the design of the tool (including identifying greenery forms, functions, scoring) as well as to building a comprehensive and rigorous evidence base to support decision making, policy adoption and roll out of the tool. The stages in the tool's development are summarized in Table 1.

\subsection{Stage 1: Identifying Green Infrastructure Forms and Functions}

The first stage for tool development involved defining the different forms and functions of greenery that the tool would include. The forms largely correspond with typologies commonly utilised by landscape architects, design- 
Table 1. Green Factor Tool development stages.

\begin{tabular}{ll}
\hline Stage & Detail \\
\hline 1. April 2019 & Identifying green infrastructure forms and functions \\
2. April 2019 & Prioritising functions \\
3. April-May 2019 & Researching the evidence base \\
4. May 2019 & Rating the vegetation forms for relative delivery of functions \\
5. May-June 2019 & Peer review of scoring and evidence matrix: practitioners and researchers \\
6. June-December 2019 & Finalisation of Tool design, piloting \\
\hline
\end{tabular}

ers and urban ecologists (Bull, 2014): large tree $(10 \mathrm{~m}$ or more); medium tree $(6 m-10 m)$; small tree $(3 m-6 m)$ and climbers (on structures); large shrub ( $2 \mathrm{~m}$ or more); small shrub (up to $2 \mathrm{~m}$ ); ground cover and understorey; lawn or turf (mown). The functions provided by greenery, that are relevant for the urban context and deliverable at building scale were identified, based on reviewing both urban ecosystem services (Gómez-Baggethun et al., 2013) and City of Melbourne's policy priorities for urban greening (CoM, 2017). The eight functions identified were: urban temperature regulation (cooling effect); habitat for biodiversity; run off mitigation; air purification; food supply; recreation; place values and social cohesion; and aesthetic benefits. Of these eight functions, three are 'regulating ecosystem services' (providing biophysical functions), and three are 'cultural ecosystem services.' As such, the tool recognises the significant contribution that ecosystems, vegetation and urban nature can make to both environmental and social outcomes, consistent with the large body of socialecological research (Lafortezza, Chen, van den Bosch, \& Randrup, 2018; McPhearson, Haase, Kabisch, \& Gren, 2016). The tool aims to balance comprehensiveness with ease of use, so not all of the possible urban ecosystem services were included; instead the tool focused on those ecosystem services that could feasibly deliver benefits at the lot scale. Ecosystem services that require larger scale greenery to provide the function were not included. For example, while carbon sequestration is an important ecosystem service, due to the relatively low quantities of sequestered carbon associated with lot scale greening in urban areas (Chen et al., 2020), it was not included in the tool.

\subsection{Stage 2: Prioritising Functions}

The second stage focused on prioritising the functions (ecosystem services). A workshop was held with City of Melbourne staff from a range of policy domains (Council departments) to prioritise the functions based on local strategic priorities, as well as with reference to local context and conditions. The workshop participants were drawn from strategic and statutory planning, urban design, open space planning, urban landscapes management, landscape architecture and urban ecology. As such, the process for prioritising functions involved input from a range of disciplines, including, but not limited to environmental or landscape planning domains. This ensured that a wide range of policy priorities and objectives were considered and assessed. Workshop participants together discussed and negotiated the relative priority of the different functions, based on policy priorities, as well as their experience of how urban greenery, vegetation and landscaping elements are incorporated into development plans (Table 2).

\subsection{Stage 3: Researching the Evidence Base}

The third stage involved building the evidence base, which demonstrates the delivery of each of the identified ecosystem services, to underpin the Green Factor Tool's rigor and credibility. Policy makers favour locally

Table 2. Stage 2: Prioritising functions.

\begin{tabular}{ll}
\hline Function priority (highest first) & Ecosystem service \\
\hline 1. Urban temperature regulation (cooling) & Regulating \\
2. Habitat for biodiversity & Supporting \\
3. Runoff mitigation & Regulating \\
4. Recreation & Cultural \\
5. Air purification & Regulating \\
6. Place values and social cohesion & Cultural \\
7. Aesthetic benefits & Cultural \\
8. Food Supply & Provisioning \\
\hline
\end{tabular}


based and generated research as the most relevant for informing and justifying decision-making (Bush, 2020). Therefore, the research review process was based on the following hierarchy of relevance: Melbourne, southeast Australia, southern Australia, Australia, temperate urban contexts globally. Local literature reviews (Davern, Farrar, Kendal, \& Giles-Corti, 2017; Kendal, Lee, Ramalho, Bowen, \& Bush, 2016) were utilized to identify relevant research, as well as identifying key local green infrastructure researchers. In addition, the Scopus research database was used to identify the most recent relevant research findings. Database searches were based on (key word: function) and limited to (source country: Australia). The key words used in the searches were the function terms (Table 2). Citations of key references were also reviewed to identify other more recent relevant research. The research aimed to identify the most local findings that demonstrated delivery of the function by the different forms of vegetation. As such, the research process sought to create a context specific, rather than comprehensive evidence base. A matrix of forms and functions was created to summarise the research and record sources.

The resulting research evidence-base matrix included a summary of how vegetation delivered each of the ecosystem functions and the key characteristics associated with maximising the function's delivery (Table 3 ). The evidence base matrix also included details differentiating the relative delivery of each function for each vegetation form. For example, tree canopy contributes both shade and evapo-transpiration for urban temperature regulation, whereas understorey vegetation provides only evapo-transpiration. The research identified 73 key sources of research on these functions, including journal articles, books, and reports.

\subsection{Stage 4: Rating the Vegetation Forms for Relative Delivery of Functions}

Following the development of the research evidence base, the fourth stage involved rating each of the vegetation form's delivery for each of the functions. The urban greening forms (large tree, medium tree, etc.) were rated between 0 (no contribution), 0.5 (minimal contribution), 1 (minor contribution), 1.5 (minor-moderate contribution), 2 (moderate contribution), 2.5 (moderatemajor contribution) to 3 (major contribution) in terms of their relative capacity to deliver each of the functions. The determination of the relative capacity of the different forms was based on research findings identified in stage 3 , and related to whether the delivery of the function was proportional to size (or height) of vegetation, or other factors such as visual amenity or food production (Table 4). Higher ratings were allocated for use of locally native (indigenous) plant species. The rating of forms, combined with the weighting of functions, generates a Green Factor Score that enables the assessment of the different types of green infrastructure provision and design (ground level landscaping, green roofs, walls and facades) for new developments. The scoring underpins a focus on achieving City of Melbourne's policy objectives that span sustainable building performance, urban ecology and biodiversity, social health, and wellbeing.

\subsection{Stage 5: Peer Review of Scoring and Evidence Matrix: Practitioners and Researchers}

Using the evidence-base matrix that details the forms and associated scores for each of the functions and the supporting research, four separate workshops were held during May 2019 to peer review the research outputs. Workshop one was with one landscape architecture researcher; workshop two was with three urban ecology researchers; workshop three was with more than 10 green infrastructure and urban ecology researchers; and workshop four was with four Council staff from the landscape and planning teams. Discussion focused on reviewing the local research on delivery of functions by different forms, and on the proposed scoring system.

The peer review process was an important element of the overall research process and tool development, particularly in being able to provide multi-disciplinary feedback and comments on the evidence-base matrix. The tool development aimed to construct a tool that is as comprehensive as possible, yet also focuses on the key functions and benefits that vegetation could deliver at lot scale. Importantly, the peer review process led to the removal of air purification from the tool, leaving seven key functions (Table 5). While there was recognition of the documented role of vegetation in mitigating different forms of air pollution (Escobedo \& Nowak, 2009; Jayasooriya, Ng, Muthukumaran, \& Perera, 2017; Tiwari et al., 2019), discussions with local researchers highlighted that Australian cities are not exposed to the same magnitude of urban air quality challenges, compared with many other cities around the world. This is largely due to existing Australian regulations and standards for vehicle emissions, which are a main source of urban air pollution (Chang et al., 2019). Further, our peer reviewers suggested that the most effective and efficient way to continue to address urban air quality is through emissions standards rather than suggesting (or implying through inclusion of air quality in the Green Factor Tool) that vegetation should be expected to mitigate this type of pollution.

With the finalisation of function weightings, combined with the ratings of vegetation forms in delivery of functions, a Green Factor Score can be generated. The Score represents the proportion of a site covered by greenery, and weighted for provision of prioritised functions.

\subsection{Finalisation of Tool Design and Piloting}

Following the finalisation of the research evidence-base, and scoring of functions and forms, the web-based tool 
Table 3. Summary of research evidence-base matrix.

\begin{tabular}{|c|c|c|c|c|}
\hline Function & $\begin{array}{l}\text { Vegetation's role in } \\
\text { ecosystem function }\end{array}$ & $\begin{array}{l}\text { Mechanism for } \\
\text { delivery }\end{array}$ & $\begin{array}{l}\text { Key determinants of } \\
\text { relative delivery }\end{array}$ & $\begin{array}{l}\text { Selected key } \\
\text { references }\end{array}$ \\
\hline $\begin{array}{l}\text { 1. Urban } \\
\text { temperature } \\
\text { regulation } \\
\text { (cooling) }\end{array}$ & $\begin{array}{l}\text { Vegetation can } \\
\text { reduce urban heat } \\
\text { and contribute to } \\
\text { human thermal } \\
\text { comfort }\end{array}$ & $\begin{array}{l}\text { Shade } \\
\text { Evapo-transpiration }\end{array}$ & $\begin{array}{l}\text { Leaf area } \\
\text { Canopy volume } \\
\text { Degree of irrigation }\end{array}$ & $\begin{array}{l}\text { Duncan et al. (2019); } \\
\text { Livesley, McPherson, } \\
\text { and Calfapietra (2016 }\end{array}$ \\
\hline
\end{tabular}

\section{Habitat for biodiversity}

\author{
Shelter \\ Food \\ 'Benevolence' \\ (conditions to enable \\ completion of life cycle)
}

\begin{abstract}
3. Runoff mitigation
\end{abstract}

Vegetation and soil can reduce the quantity of stormwater runoff

$\begin{array}{ll}\text { 4. Recreation } & \text { Vegetation/green } \\ & \text { space can provide } \\ & \text { opportunities and } \\ & \text { location for } \\ & \text { recreation }\end{array}$

5. Air purification

6. Place values
and social
cohesion

\section{Aesthetic} benefits

\section{Food Supply Vegetation can produce food, fibre, etc}

Soil water retention: permeability/percolation Canopy interception

\author{
Doing (active) and being \\ (passive) in accessible \\ green space: physical \\ activity (walking, \\ gardening), play \\ Dry deposition (surface \\ area) Atmospheric \\ turbulence (surface \\ roughness)
}

Emotional and spiritual connections; cultural landscapes; sense of place; shared interests, participation
Species: indigenous Structural complexity No pesticides or pollutants; minimise noise, disturbance, night time light

Substrate volume Substrate permeability Leaf area Canopy volume

Accessibility
Davern et al. (2017); McCormick (2017)

Maclagan, Coates, and Ritchie (2018); Parris et al. (2018); Shaw, Miller, and Wescott (2017); Threlfall et al. (2016, 2017)

Livesley et al. (2016); Ossola, Hahs, and Livesley (2015)$$
\text { McCormick (2017) }
$$

Leaf level attributes (hairiness, waxiness) Leaf area

Canopy volume

Community scale/social cohesion Visibility Accessibility

Visibility psychological benefits, stress reduction, recovery; sense of wellbeing

Food production, connection with broader food system

\section{Escobedo and Nowak (2009); Tiwari et al. (2019)}

Davern et al. (2017); Dickinson and Hobbs (2017)

Davern et al. (2017); Lin, Egerer, and Ossola (2018)
Lin et al. (2018);

Zainuddin and Mercer (2014) was developed. Unlike many of the Green Factor Tools used in other cities, the City of Melbourne version utilises a web interface. This allows 'open access' (without relying on users needing licence access to Excel spreadsheets) as well as opportunities for a more user-friendly interface design and usability, and the ability for the tool owner (in this case City of Melbourne) to update the tool without concerns for version control.
The web-based tool (CoM, 2020) calculates a Green Factor Score based on the relative volume and weighting of green elements, in comparison to the overall area of the site. The first step requires tool users to enter details on the project site, including address, total site land area, land use and building typology (smallscale residential, multi-unit residential, retail/shop, commercial/office, industrial/warehousing, or public build- 
Table 4. Delivery of functions rated for different vegetation forms.

\begin{tabular}{|c|c|c|c|c|c|c|c|}
\hline & $\begin{array}{l}\text { Large tree } \\
10 \mathrm{~m}+\end{array}$ & $\begin{array}{l}\text { Medium } \\
\text { tree } \\
6 m-10 m\end{array}$ & $\begin{array}{l}\text { Small tree } \\
3 m-6 m \\
\& \text { climbers } \\
\text { (on structure) }\end{array}$ & $\begin{array}{l}\text { Large shrub } \\
2 m+\end{array}$ & $\begin{array}{l}\text { Small shrub } \\
\text { up to } 2 \mathrm{~m}\end{array}$ & $\begin{array}{l}\text { Ground } \\
\text { cover/ } \\
\text { under-storey }\end{array}$ & Lawn/turf \\
\hline $\begin{array}{l}\text { 1. Temperature } \\
\text { regulation }\end{array}$ & 3 & 3 & 2.5 & 2 & 2 & $\begin{array}{l}2^{*} \\
1^{* *}\end{array}$ & $\begin{array}{l}2^{*} \\
1 * *\end{array}$ \\
\hline 2. Habitat provision & 3 & 3 & 2.5 & 2 & 2 & 1.5 & 0.5 \\
\hline 3. Runoff (quantity) & 3 & 3 & 2.5 & 2 & 2 & 2 & 2 \\
\hline 4. Recreation & 3 & 3 & 2.5 & 1 & 1 & 1 & 2 \\
\hline 5. Air purification & 3 & 3 & 3 & 3 & 3 & 1 & 0 \\
\hline $\begin{array}{l}\text { 6. Place and social } \\
\text { cohesion }\end{array}$ & 3 & 3 & 3 & 2 & 2 & 2 & 1 \\
\hline 7. Aesthetic & 3 & 3 & 3 & 2 & 2 & 2 & 2 \\
\hline 8. Food production & $2 * * *$ & $2 * * *$ & $2 * * *$ & $2 * * *$ & $2 * * *$ & $3 * * *$ & 0 \\
\hline
\end{tabular}

Notes: ${ }^{*}=$ irrigated, ${ }^{* *}=$ unirrigated, ${ }^{* * *}=$ productive food only.

ing) and a short description of the proposed development. The second and main step is for tool users to enter details of the green infrastructure elements (type and area) of their proposed development. For the purposes of the tool, 'green infrastructure' includes both vegetation and soil elements. The tool requires that users specify whether the green infrastructure is in ground (existing retained), inground (new), green wall, green façade, planters (on structure), or green roof. Based on the input data, the tool generates a Green Factor Score that takes into account the relative volume and efficacy of green elements, in comparison to the overall area of the site.

Following completion of the tool's design and construction, it entered a pilot stage (July 2019-February 2020) for testing and calibration. The pilot stage had the objectives of ensuring that the tool is robust and capable of application by different users (the tool is designed to be used by landscape architects, architects, Ecologically Sustainable Development consultants and other built environment professionals) and to the range of expected green infrastructure assessments. The pilot stage also included a process for determining a target Green Factor Score that design proposals will need to meet. To determine this, a range of different designs for residential, commercial and industrial developments were inputted to the tool to assess the spread of Green Factor Scores for different amounts and forms of greenery in different development contexts. This process helped to ensure that the settings were sufficiently sensitive to differentiate between designs.

Targets for Green Factor Scores were set at 0.55 for residential and commercial developments (corresponding to a horizontal green cover of $40 \%$ site coverage), and 0.25 for industrial developments (CoM, 2020). The Green Factor Score is lower for industrial building typologies because the piloting process found that opportunities to integrate greenery are more limited in industrial contexts due to requirements for creating clear access for both delivery and emergency vehicles. Following the piloting process, the Tool was made publicly available for voluntary use by developers (CoM, 2020), with an online launch held on 26 May 2020. The City of Melbourne's policy development approach is to monitor the tool's use by designers and developers during this voluntary phase, with the intention to pursue changes to the Melbourne Planning Scheme, that would integrate an assessment metric for greening targets (CoM, 2017). There is a need for future research to assess and analyse the impacts

Table 5. Urban Ecosystem Services in order of priority included in the Green Factor Tool.

\begin{tabular}{lcc}
\hline Function & Weighting & Ecosystem service \\
\hline 1. Urban temperature regulation (cooling) & $25 \%$ & Regulating \\
2. Habitat for biodiversity & $20 \%$ & Supporting \\
3. Runoff mitigation & $20 \%$ & Regulating \\
4. Food supply & $10 \%$ & Provisioning \\
5. Recreation & $10 \%$ & Cultural \\
6. Place values and social cohesion & $10 \%$ & Cultural \\
7. Aesthetic benefits & $5 \%$ & Cultural \\
\hline
\end{tabular}


of the tool's use in achievement of City of Melbourne's greening and environmental sustainability targets and objectives. Further research could also include comparative analysis of Melbourne's Green Factor Tool and those of other cities including Berlin, Helsinki, Malmö, Seattle and Singapore.

\section{Discussion}

The development of Melbourne's Green Factor Tool was underpinned by a staged process that involved input from both researchers and practitioners at multiple points, to complement the review and assembly of the research evidence base. The transdisciplinary process was supported by the assembly of an effective consultancy team with complementary skills, clear communication channels, and clear allocation of specific tasks with clear timelines. The development of the Green Factor Tool demonstrates how local governments can support transdisciplinarity by requiring academic input to consultancies and by valuing academic research as an essential element of the evidencebase. As such, this article contributes to understandings of effective models for exchange and collaboration between researchers and planners in urban planning (Hurley, Lamker, \& Taylor, 2016).

The peer review process strengthened the rigour of the research evidence base, as demonstrated by the review and removal of air quality from the list of vegetation functions included in the Tool. However, the lack of inclusion of air quality as one of the Tool's functions was questioned during the pilot phase, and particularly during the summer of 2020 when many of Australia's cities were blanketed in smoke from catastrophic bushfires (Head, 2020). As urban Australians struggled to breath, with some cities experiencing thick smoke for up to one month, there was a renewed focus on the health impacts of smoke and other sources of air pollution (Vardoulakis, Marks, \& Abramson, 2020; Walter, Schneider-Futschik, Knibbs, \& Irving, 2020). However, urban vegetation would have had minimal effects in mitigating the sheer magnitude of smoke generated by the bushfires, which was observed by NASA satellites as it circled the globe. Nonetheless, the tool development process, which involved a thorough research process, followed by the peer review process, provided policy makers with a credible and reliable evidence base, as well as a degree of confidence, when called upon to explain and justify the inclusion or exclusion of functions and the construction of the scoring and targets for the tool.

Likewise, City of Melbourne's suite of greening policies has also been important in building awareness, interest, support and capacity for increasing greening implementation. The comprehensive suite of greening policies now spans policies for the public and private realms; addresses urban forest and tree canopy, green roofs, walls and facades, urban ecology and biodiversity; encompasses community engagement, skills and industry development; and planting on local government managed land as well as funding provision for greening on land owned and managed by others (Table 6). Likewise, the Green Factor Tool itself is intended to shift through pilot and voluntary phases before its inclusion in the planning scheme requiring mandatory application. As such, this diversity of approaches can be seen to have contributed to a multi-pronged approach to increasing greening uptake across the municipality that addresses strategic, operational and engagement dimensions of policy development, and potentially underpins and increases policy success (Bush, 2020).

\section{Conclusions}

The development of City of Melbourne's Green Factor Tool has shown how research can inform and support policy development, and how transdisciplinary collaboration can lead to more rigorous and locally relevant outcomes. The tool's development was underpinned by peer reviewed research, both in its reliance on research to build the supporting evidence base, and in the peer

Table 6. Development of City of Melbourne's greening policy suite (selected policies and programs).

\begin{tabular}{llll}
\hline Year & Policy & Greening context & Key areas of focus \\
\hline 2011 & Citizen Forester program & Public green space & Community engagement \\
2012 & Urban Forest Strategy & Tree canopy, public realm & Strategic planning \\
2014 & Growing Green Guide & Green roofs, walls and facades & Technical guide \\
2015 & Canopy quarterly discussion forum & Green roofs, walls and facades & Industry skills development \\
2016 & Green your laneway pilot & Green roofs, walls and facades & Funding \\
2017 & Nature in the city strategy & Urban ecology, biodiversity & Strategic planning \\
2017 & Green Our City Strategic Action Plan & Green roofs, walls and facades & Strategic planning \\
2018 & Urban Forest Fund & Urban greening & Funding \\
$2019-2021$ & Green Factor Tool & Greening private realm & Voluntary-mandatory planning \\
& & & provision \\
\hline
\end{tabular}

Source: Adapted from CoM (2017). 
review process of the tool's development. This research input supported the development of a rigorous and credible tool, and strengthened policy makers' confidence in the final tool output.

The resulting Green Factor Tool is available for use through a web-based interface (CoM, 2020). It has been designed for use by landscape architects, architects, environmentally sustainable design consultants and other built environment professionals as part of the development approval process. The development of the tool has sought to balance comprehensiveness with ease of use to promote its uptake. The tool's design brings together research on the functions (ecosystem services) provided by green infrastructure at the lot scale, with the policy priorities and objectives of the City of Melbourne, to weight and score the green infrastructure contributions.

The development of the Green Factor Tool demonstrates local government leadership in supporting the increased provision of greenery in new development. The tool and its development process can be applied by other cities, to contribute towards objectives of increased greenery within urban buildings and precincts. Further research will be necessary to assess and analyse the tool's contribution to increasing greening and environmental sustainability outcomes as the tool is integrated into urban development planning and approval processes. As more cities adopt these regulatory tools, further research to provide comparative analysis of the tools will be important to inform and encourage bestpractice approaches.

\section{Acknowledgments}

The authors thank all those involved in the workshops that informed the development of the Green Factor Tool. The authors thank the Academic Editors and reviewers for their valuable feedback and comments on this article.

\section{Conflict of Interests}

All authors were involved in the development of the Green Factor Tool. Judy Bush and Gavin Ashley were part of the consultancy team appointed by City of Melbourne to develop the Green Factor Tool. Ben Foster and Gail Hall were both employed by City of Melbourne during the development of the Green Factor Tool. Ben Foster is currently employed by City of Melbourne.

\section{References}

Aalbers, C. B. E. M., Kamphorst, D. A., \& Langers, F. (2019). Fourteen local governance initiatives in greenspace in urban areas in the Netherlands: Discourses, success and failure factors, and the perspectives of local authorities. Urban Forestry and Urban Greening, 42, 82-99. https://doi.org/10.1016/j.ufug.2019.04.019

Ade, R., \& Rehm, M. (2020). The unwritten history of green building rating tools: A personal view from some of the 'founding fathers.' Building Research and Information, 48(1), 1-17. https://doi.org/10.1080/ 09613218.2019.1627179

Bathgate, R., Williams, N. S. G., Sargent, L., Lee, K. E., Rayner, J. P., Ritchie, M., . . . Martin, C. (2020). Roadmap for green roofs, walls and facades in Australia's urban landscapes 2020-2030. Melbourne: University of Melbourne, University of NSW, and Hort Innovation.

Bull, M. (2014). Flora of Melbourne: A guide to the indigenous plants of the greater Melbourne area (4th ed.). Carlton: Hyland House Publishing.

Bush, J. (2020). The role of local government greening policies in the transition towards nature-based cities. Environmental Innovation and Societal Transitions, 35, 35-44. https://doi.org/10.1016/j.eist.2020. 01.015

Bush, J., \& Doyon, A. (2019). Building urban resilience with nature-based solutions: How can urban planning contribute? Cities, 95, 102-483. https://doi.org/ 10.1016/j.cities.2019.102483

Chang, L. T. C., Scorgie, Y., Duc, H. N., Monk, K., Fuchs, D., \& Trieu, T. (2019). Major source contributions to ambient PM2.5 and exposures within the New South Wales Greater Metropolitan Region. Atmosphere, 10(3). https://doi.org/10.3390/atmos10030138

Chen, S., Chen, B., Feng, K., Liu, Z., Fromer, N., Tan, X., ... Hubacek, K. (2020). Physical and virtual carbon metabolism of global cities. Nature Communications, 11(1). https://doi.org/10.1038/s41467-019-13757-3

Climate-ADAPT. (2016). Berlin Biotope Area Factor: Implementation of guidelines helping to control temperature and runoff. Climate-ADAPT. Retrieved from https://climate-adapt.eea.europa.eu/metadata/ case-studies/berlin-biotope-area-factor-2013implementation-of-guidelines-helping-to-controltemperature-and-runoff

Cohen-Shacham, E., Walters, G., Janzen, C., \& Maginnis, S. (2016). Nature-based solutions to address global societal challenges. Gland: IUCN.

CoM. (2012). Urban forest strategy: Making a great city greener (2012-2032). Melbourne: City of Melbourne.

CoM. (2014). Opportunities assessment for greening laneways: Report by Arup for City of Melbourne. Melbourne: City of Melbourne.

CoM. (2017). Green our city strategic action plan: Vertical and rooftop greening in Melbourne. Melbourne: City of Melbourne.

CoM. (2020). Green factor tool. City of Melbourne. Retrieved from https://www.melbourne.vic.gov.au/ community/greening-the-city/green-infrastructure/ Pages/green-factor-tool.aspx

Connop, S., Vandergert, P., Eisenberg, B., Collier, M. J., Nash, C., Clough, J., \& Newport, D. (2016). Renaturing cities using a regionally-focused biodiversityled multifunctional benefits approach to urban green infrastructure. Environmental Science and Policy, 
62, 99-111. https://doi.org/10.1016/j.envsci.2016. 01.013

Cortinovis, C., \& Geneletti, D. (2018). Ecosystem services in urban plans: What is there, and what is still needed for better decisions. Land Use Policy, 70, 298-312. https://doi.org/10.1016/j.landusepol.2017.10.017

Davern, M., Farrar, A., Kendal, D., \& Giles-Corti, B. (2017). Quality green public open space supporting health, wellbeing and biodiversity: A literature review. Victoria: University of Melbourne.

Dickinson, D. C., \& Hobbs, R. J. (2017). Cultural ecosystem services: characteristics, challenges and lessons for urban green space research. Ecosystem Services, 25, 179-194. https://doi.org/10.1016/j.ecoser.2017. 04.014

Duncan, J. M. A., Boruff, B., Saunders, A., Sun, Q., Hurley, J., \& Amati, M. (2019). Turning down the heat: An enhanced understanding of the relationship between urban vegetation and surface temperature at the city scale. Science of The Total Environment, 656, 118-128. https://doi.org/10.1016/ j.scitotenv.2018.11.223

Egerer, M. H., Philpott, S. M., Bichier, P., Jha, S., Liere, H., \& Lin, B. B. (2018). Gardener well-being along social and biophysical landscape gradients. Sustainability, 10(1). https://doi.org/10.3390/su10010096

Escobedo, F. J., \& Nowak, D. J. (2009). Spatial heterogeneity and air pollution removal by an urban forest. Landscape and Urban Planning, 90(3/4), 102-110. https://doi.org/10.1016/j.landurbplan.2008.10.021

GHD. (2013). Green infrastructure and the private realm: International review. Unpublished report.

Gómez-Baggethun, E., Gren, Å., Barton, D. N., Langemeyer, J., McPhearson, T., O'Farrell, P., . . . Kremer, P. (2013). Urban ecosystem services. In T. Elmqvist, M. Fragkias, J. Goodness, B. Güneralp, P. J. Marcotullio, R. I. McDonald, ... C. Wilkinson (Eds.), Urbanization, biodiversity and ecosystem services: Challenges and opportunities. A global assessment (pp. 175-251). Dordrecht: Springer.

Haase, D., Larondelle, N., Andersson, E., Artmann, M., Borgstrom, S., Breuste, J., . . . Elmqvist, T. (2014). A quantitative review of urban ecosystem service assessments: Concepts, models, and implementation. $A M B I O, 43,413-433$. https://doi.org/10.1007/ s13280-014-0504-0

Hansen, R., Frantzeskaki, N., McPhearson, T., Rall, E., Kabisch, N., Kaczorowska, A., . . Pauleit, S. (2015). The uptake of the ecosystem services concept in planning discourses of European and American cities. Ecosystem Services, 12, 228-246. https://doi.org/ 10.1016/j.ecoser.2014.11.013

Hansen, R., \& Pauleit, S. (2014). From multifunctionality to multiple ecosystem services? A conceptual framework for multifunctionality in green infrastructure planning for urban areas. $A M B I O, 43(4), 516-529$. https://doi.org/10.1007/s13280-014-0510-2

Head, L. (2020). Transformative change requires resist- ing a new normal. Nature Climate Change. https:// doi.org/10.1038/s41558-020-0712-5

Hurley, J., Lamker, C. W., \& Taylor, E. J. (2016). Exchange between researchers and practitioners in urban planning: Achievable objective or a bridge too far? Planning Theory and Practice, 17(3), 447-453. https:// doi.org/10.1080/14649357.2016.1190491

IPBES. (2019). Global assessment report on biodiversity and ecosystem services of the Intergovernmental Science-Policy Platform on Biodiversity and Ecosystem Services. Bonn: IPBES Secretariat.

Ives, C. D., Lentini, P. E., Threlfall, C. G., Ikin, K., Shanahan, D. F., Garrard, G. E., . . Kendal, D. (2016). Cities are hotspots for threatened species. Global Ecology and Biogeography, 25(1), 117-126. https://doi.org/ 10.1111/geb.12404

Jayasooriya, V. M., Ng, A. W. M., Muthukumaran, S., \& Perera, B. J. C. (2017). Green infrastructure practices for improvement of urban air quality. Urban Forestry and Urban Greening, 21. https://doi.org/10.1016/ j.ufug.2016.11.007

Juhola, S. (2018). Planning for a green city: The Green Factor tool. Urban Forestry and Urban Greening, 34, 254-258. https://doi.org/10.1016/j.ufug.2018. 07.019

Kabisch, N., van den Bosch, M., \& Lafortezza, R. (2017). The health benefits of nature-based solutions to urbanization challenges for children and the elderly: A systematic review. Environmental Research, 159, 362-373. https://doi.org/10.1016/j.envres.2017.08. 004

Kendal, D., Lee, K., Ramalho, C., Bowen, K., \& Bush, J. (2016). Benefits of urban green space in the Australian context: A synthesis review for the Clean Air and Urban Landscapes hub of the National Environmental Science Program. Melbourne: Clean Air and Urban Landscapes Hub.

Kowarik, I., Fischer, L. K., \& Kendal, D. (2020). Biodiversity conservation and sustainable urban development. Sustainability, 12(12). https://doi.org/ $10.3390 /$ su 12124964

Kruuse, A. (2011). GRaBS expert paper 6: The green space factor and the green points system. London: UK Town and Country Planning Association.

Lafortezza, R., Chen, J., van den Bosch, C. K., \& Randrup, T. B. (2018). Nature-based solutions for resilient landscapes and cities. Environmental Research, 165, 431-441. https://doi.org/10.1016/j.envres.2017.11. 038

Lin, B. B., Egerer, M. H., \& Ossola, A. (2018). Urban gardens as a space to engender biophilia: Evidence and ways forward. Frontiers in Built Environment, 4. https://doi.org/10.3389/fbuil.2018.00079

Liu, L., \& Jensen, M. B. (2018). Green infrastructure for sustainable urban water management: Practices of five forerunner cities. Cities, 74, 126-133. https:// doi.org/10.1016/j.cities.2017.11.013

Livesley, S. J., McPherson, G. M., \& Calfapietra, C. (2016). 
The urban forest and ecosystem services: Impacts on urban water, heat, and pollution cycles at the tree, street, and city scale. Journal of Environmental Quality, 45(1), 119-124. https://doi.org/10.2134/jeq2015. 11.0567

Maclagan, S. J., Coates, T., \& Ritchie, E. G. (2018). Don't judge habitat on its novelty: Assessing the value of novel habitats for an endangered mammal in a peri-urban landscape. Biological Conservation, 223, 11-18. https://doi.org/10.1016/j.biocon.2018. 04.022

Marshall, A. J., Grose, M. J., \& Williams, N. S. G. (2019). From little things: more than a third of public green space is road verge. Urban Forestry and Urban Greening, 44. https://doi.org/10.1016/j.ufug.2019.126423

McCormick, R. (2017). Does access to green space impact the mental well-being of children: A systematic review. Journal of Pediatric Nursing. https://doi. org/10.1016/j.pedn.2017.08.027

McPhearson, T., Haase, D., Kabisch, N., \& Gren, Å. (2016). Advancing understanding of the complex nature of urban systems. Ecological Indicators, 70. https://doi. org/10.1016/j.ecolind.2016.03.054

Meerow, S. (2020). The politics of multifunctional green infrastructure planning in New York City. Cities, 100, 102-621. https://doi.org/10.1016/j.cities.2020. 102621

Millennium Ecosystem Assessment. (2003). Ecosystems and human well-being: A framework for assessment. Washington, DC: Island Press.

Ong, B. L. (2003). Green Plot Ratio: An ecological measure for architecture and urban planning. Landscape and Urban Planning, 63(4), 197-211. https://doi.org/10.1016/S0169-2046(02)00191-3

Ossola, A., Hahs, A. K., \& Livesley, S. J. (2015). Habitat complexity influences fine scale hydrological processes and the incidence of stormwater runoff in managed urban ecosystems. Journal of Environmental Management, 159, 1-10. https://doi.org/10.1016/ j.jenvman.2015.05.002

Parris, K. M., Amati, M., Bekessy, S. A., Dagenais, D., Fryd, O., Hahs, A. K., ... Williams, N. S. G. (2018). The seven lamps of planning for biodiversity in the city. Cities, 83, 44-53. https://doi.org/10.1016/j.cities.2018.06. 007

Pauleit, S., Ambrose-Oji, B., Andersson, E., Anton, B., Buijs, A., Haase, D., . . . van der Jagt, A. P. N. (2018). Advancing urban green infrastructure in Europe: Outcomes and reflections from the GREEN SURGE project. Urban Forestry and Urban Greening, 40, 4-16. https://doi.org/10.1016/j.ufug.2018.10.006

Phelan, K., Hurley, J., \& Bush, J. (2018). Land-use planning's role in urban forest strategies: Recent local government approaches in Australia. Urban Policy and Research, 37(2), 215-226. https://doi.org/10.1080/ 08111146.2018 .1518813

Santamouris, M., Ban-Weiss, G., Osmond, P., Paolini, R., Synnefa, A., Cartalis, C., . . . Kolokotsa, D.
(2018). Progress in urban greenery mitigation science: Assessment methodologies advanced technologies and impact on cities. Journal of Civil Engineering and Management, 24(8), 638-671. https:// doi.org/10.3846/jcem.2018.6604

Scott, M., Lennon, M., Haase, D., Kazmierczak, A., Clabby, G., \& Beatley, T. (2016). Nature-based solutions for the contemporary city/re-naturing the city/reflections on urban landscapes, ecosystems services and nature-based solutions in cities/multifunctional green infrastructure and climate change adaptation: Brownfield greening as an adaptation strategy for vulnerable communities?/Delivering green infrastructure through planning: Insights from practice in Fingal, Ireland/Planning for biophilic cities: From theory to practice. Planning Theory and Practice, 17(2), 267-300. https://doi.org/10.1080/14649357.2016. 1158907

Shaw, A., Miller, K. K., \& Wescott, G. (2017). Australian native gardens: Is there scope for a community shift? Landscape and Urban Planning, 157, 322-330. https://doi.org/10.1016/j.landurbplan.2016.07.009

Slätmo, E., Nilsson, K., \& Turunen, E. (2019). Implementing green infrastructure in spatial planning in Europe. Land, 8(4). https://doi.org/10.3390/land8040062

Threlfall, C. G., Mata, L., Mackie, J. A., Hahs, A. K., Stork, N. E., Williams, N. S. G., \& Livesley, S. J. (2017). Increasing biodiversity in urban green spaces through simple vegetation interventions. Journal of Applied Ecology, 54(6), 1874-1883. https://doi.org/10.1111/13652664.12876

Threlfall, C. G., Ossola, A., Hahs, A. K., Williams, N. S. G., Wilson, L., \& Livesley, S. J. (2016). Variation in vegetation structure and composition across urban green space types. Frontiers in Ecology and Evolution, 4. https://doi.org/10.3389/fevo.2016.00066

Tiwari, A., Kumar, P., Baldauf, R., Zhang, K. M., Pilla, F., Di Sabatino, S., . . . Pulvirenti, B. (2019). Considerations for evaluating green infrastructure impacts in microscale and macroscale air pollution dispersion models. Science of The Total Environment, 672, 410-426. https://doi.org/10.1016/ j.scitotenv.2019.03.350

TNC, \& RM. (2019). Living Melbourne: Our metropolitan urban forest. Melbourne: The Nature Conservancy and Resilient Melbourne.

Vardoulakis, S., Marks, G., \& Abramson, M. J. (2020). Lessons learned from the Australian bushfires: Climate change, air pollution, and public health. JAMA Internal Medicine, 180(5), 635-636. https://doi.org/ 10.1001/jamainternmed.2020.0703

Victorian Department of Environment and Primary Industries. (2014). Growing green guide: A guide to green roofs, walls and facades in Melbourne and Victoria, Australia. Melbourne: Victorian Department of Environment and Primary Industries.

Walter, C. M., Schneider-Futschik, E. K., Knibbs, L. D., \& 
Irving, L. B. (2020). Health impacts of bushfire smoke exposure in Australia. Respirology, 25(5), 495-501. https://doi.org/10.1111/res13798p

Zainuddin, Z., \& Mercer, D. (2014). Domestic residen- tial garden food production in Melbourne, Australia: A fine-grained analysis and pilot study. Australian Geographer, 45(4), 465-484. https://doi.org/ $10.1080 / 00049182.2014 .954299$

\section{About the Authors}

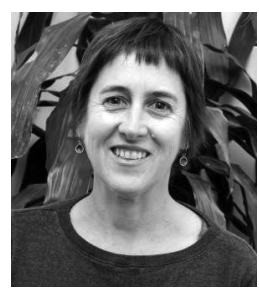

Judy Bush is a Lecturer in Urban Planning in the Faculty of Architecture, Building and Planning at the University of Melbourne. Her research is focused on urban environmental policy and climate change, and with a particular interest in the roles of urban green spaces, urban ecology and nature-based solutions for liveable cities.

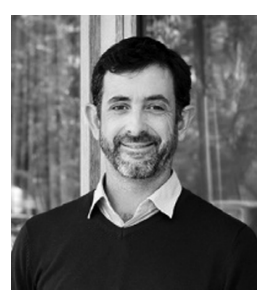

Gavin Ashley leads the Better Cities \& Regions team for HIP V. HYPE Sustainability, focused on supporting sustainable urban renewal and community outcomes using both planning and non-planning delivery mechanisms. Gavin holds a Masters of Environment and Urban Planning, and experience in urban development and sustainability across the private, non-profit and public sectors and is keenly interested in how climate change responses can be better shared and delivered beyond sustainability practitioners.

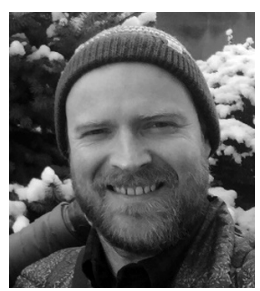

Ben Foster is an experienced Environmental Engineer who has worked in sustainable buildings policy and design for the built environment for over 12 years in consulting and local government. As the Senior Green Infrastructure and ESD Officer for the City of Melbourne he is the point of contact between the development industry and City of Melbourne sustainable planning policy. Ben managed the development of the Melbourne Green Factor tool.

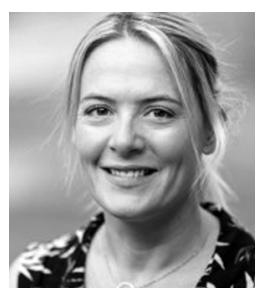

Gail Hall is an accomplished Environmental Sustainability and Green Infrastructure Specialist, who has led the development of strategy and planning policy in local government roles. She works collaboratively with internal and external stakeholders, presenting evidence-based research and proposals to influence planning and decision-making at all levels. She holds a Bachelor of Science degree, majoring in Geography. 